\title{
One-Pot Preparation of Alumina-Modified Polysulfone-Graphene Oxide Nanocomposite Membrane for Separation of Emulsion- Oil from Wastewater
}

\author{
Vuong Hoan T. Nguyen $\mathbb{D}^{1}{ }^{1}$ Minh N. Nguyen, ${ }^{1}$ Tam T. Truong, ${ }^{1}$ Tien Trung Nguyen $\mathbb{D}^{2}{ }^{2}$ \\ Huan V. Doan ${ }^{2}{ }^{2}$ and Xuan Nui Pham (iD ${ }^{2}$ \\ ${ }^{1}$ Department of Chemistry, Quy Nhon University, 170-An Duong Vuong, Quy Nhon, Binh Dinh, Vietnam \\ ${ }^{2}$ Department of Chemical Engineering, Hanoi University of Mining and Geology, 18-Vien Street, Duc Thang, Bac Tu Liem, \\ Hanoi, Vietnam
}

Correspondence should be addressed to Vuong Hoan T. Nguyen; nguyenthivuonghoan@qnu.edu.vn and Xuan Nui Pham; phamxuannui@gmail.com

Received 22 February 2020; Accepted 1 April 2020; Published 24 April 2020

Guest Editor: Ahmad Hosseini-Bandegharaei

Copyright $\odot 2020$ Vuong Hoan T. Nguyen et al. This is an open access article distributed under the Creative Commons Attribution License, which permits unrestricted use, distribution, and reproduction in any medium, provided the original work is properly cited.

\begin{abstract}
In recent years, polysulfone-based nanocomposite membranes have been widely used for contaminated water treatment because they comprise properties such as high thermal stability and chemical resistance. In this study, a polysulfone (PSf) nanocomposite membrane was fabricated using the wet-phase inversion method with the fusion of graphene oxide (GO) and alumina $\left(\mathrm{Al}_{2} \mathrm{O}_{3}\right)$ nanoparticles. We also showed that $\mathrm{GO}-\mathrm{Al}_{2} \mathrm{O}_{3}$ nanoparticles were synthesised successfully by using a one-pot hydrothermal method. The nanocomposite membranes were characterised by Fourier transform infrared (FT-IR), scanning electron microscopy (SEM), nitrogen adsorption-desorption isotherms, energy-dispersive X-ray spectroscopy (EDX), thermogravimetric analysis (TGA), and water contact angle. The loading of $\mathrm{GO}$ and $\mathrm{Al}_{2} \mathrm{O}_{3}$ was investigated to improve the hydrophilic and oil rejection of the matrix membrane. It was shown that by using $1.5 \mathrm{wt} \% \mathrm{GO}_{-} \mathrm{Al}_{2} \mathrm{O}_{3}$ loaded in polysulfone, $\sim 74 \%$ volume of oil was separated from the oil/water emulsion at 0.87 bar and $30 \mathrm{~min}$. This figure was higher than that of the process using the unmodified membrane (PSf/GO) at the same conditions, in which only $~ 60 \%$ volume of oil was separated. The $\mathrm{pH}$, oil/water emulsion concentration, separation time, and irreversible fouling coefficient $\left(\mathrm{FR}_{\mathrm{w}}\right)$ were also investigated. The obtained results suggested that the $\mathrm{GO}-\mathrm{Al}_{2} \mathrm{O}_{3}$ nanoparticles loaded in the polysulfone membrane might have potential use in oily wastewater treatment applications.
\end{abstract}

\section{Introduction}

Nowadays, a large amount of oily wastewater from different industrial processes (such as metallurgy, transportation, food processing, and petrochemical and oil refinery) has negatively impacted the environment [1]. Many conventional technologies, such as ultrasonic separation [2], coagulation and air floatation [3], microwave [4], ozonation [5], and biological processes [6], have been used for separating oil from an oil/water emulsion. However, these technologies are often restricted by their low separation efficiency and high energy cost [7]. Recently, the membrane filtration technology has been applied for separating oil from wastewater due to the advantages of energy saving, high separation efficiency, and environmental friendliness $[8,9]$. Polysulfone is known as a polymer which is used for the synthesis of filtration membranes and has outstanding properties such as mechanical and thermal stability, chemical resistance, convenient flux, and low cost $[10,11]$. However, the major drawback of this membrane type is its hydrophobic feature, which leads to membrane fouling, and this in turn reduces filtration efficiency and increases the cost of the operation process [12]. To overcome these drawbacks, many approaches have been conducted which involve using nanocarbon materials to 
modify polymeric membranes. In particular, $\mathrm{GO}$ is commonly used as an additive for the preparation of blended membranes $[13,14]$. This is because graphene oxide contains an abundance of functional groups such as hydroxyl, carboxyl, ketones, and epoxide $[15,16]$, thus making it a good choice to improve permeability and antifouling efficiency; adding to this, GO has a unique 2D nanosheet structure, large specific surface area, good mechanical properties, and high hydrophilicity [17-21]. These features improve not only the hydrophilic properties but also the mechanical properties, as well as the fouling resistance ability of membranes, particularly when filtering organic compounds $[22,23]$. In researches of oil/water emulsions, $\mathrm{Hu}$ et al. [24] developed a novel GO-modified commercial 19-channel ceramic MF membrane by a transfer via a vacuum method. Pan et al. [25] used titanium dioxide dynamic membranes in the separation of oil-in-water emulsions. The results showed high efficiency for oil rejection with low permeate concentrations.

Recently, Ji et al. [26] reported the preparation of PSf/GO loose nanofiltration hollow-fiber membranes, which effectively stored Congo red at $99.9 \%$ over a continuous period of $480 \mathrm{~min}$. Nasseri et al. [27] synthesised and characterised a PSf/GO nanocomposite membrane under optimum conditions; this membrane eliminated up to $93 \%$ of bisphenol A from the water environment. $\mathrm{PSf}-\mathrm{TiO}_{2} / \mathrm{GO}$ nanocomposite membranes were also prepared by Sirinupong et al. [28] for forwarding osmosis applications.

As mentioned above, membrane fabrication can be introduced by the incorporation of GO into polymer matric membranes because of the presence of hydrophilic functional groups on the surface. However, the insertion of GO nanoparticles into the polymeric membrane is restricted by the aggregation of thin sheets of carbon atoms. Therefore, GO nanoparticles are added to a polymer matrix with a suitable content and by using an appropriate procedure, which can significantly improve the physical properties of the membrane $[29,30]$. Furthermore, a few researches were carried out to modify the membranes by physical blending, plasma treatment [31], and polymer grafting and chemical reactions [32]. In our previous research [33], we prepared a graphene oxide-titanium dioxide $\left(\mathrm{GO}-\mathrm{TiO}_{2}\right)$ mixture into the polysulfone through a phase inversion technique for the removal of methylene blue (MB) from water. The results showed that the $\mathrm{MB}$ rejection of the $\mathrm{PSf} / \mathrm{GO}-\mathrm{TiO}_{2}$ membrane was higher than that of the unblended membranes (PSf/GO).

This research is aimed at synthesising PSf/GO- $\mathrm{Al}_{2} \mathrm{O}_{3}$ nanocomposite membranes for the rejection of oil from wastewater. In the work, $\mathrm{GO}-\mathrm{Al}_{2} \mathrm{O}_{3}$ nanoparticles were dispersed into a PSf matrix as the hydrophilic agent using a one-pot procedure. The membranes were characterised in terms of morphology, hydrophilicity, and stability. The optimal membrane was evaluated on the basis of the oil removal from an oil/water emulsion and under the optimum conditions of operating time, initial concentration of emulsion, and $\mathrm{pH}$. Moreover, the effects of $\mathrm{GO}$ and $\mathrm{GO}-\mathrm{Al}_{2} \mathrm{O}_{3}$ on the hydrophilic and antifouling properties of the blended membranes were compared by determining the rejection, permeability, irreversible fouling coefficient, and reusability of the membranes.

\section{Experimental}

2.1. Materials. Graphite powder, sodium dodecyl sulfate (SDS, 99\%), aluminium sulfate $\left(\mathrm{Al}_{2}\left(\mathrm{SO}_{4}\right)_{3}, 99.9 \%\right)$, potassium permanganate $\left(\mathrm{KMnO}_{4}, 99 \%\right)$, sodium nitrate $\left(\mathrm{NaNO}_{3}\right.$, $99 \%)$, sodium hydroxide $(\mathrm{NaOH}, 99 \%)$, ammonia solution $\left(\mathrm{NH}_{4} \mathrm{OH}, 25 \%\right)$, sulphuric acid $\left(\mathrm{H}_{2} \mathrm{SO}_{4}, 98 \%\right)$, hydrochloric acid $(\mathrm{HCl}, 37 \%)$, ethanol $\left(\mathrm{C}_{2} \mathrm{H}_{5} \mathrm{OH}, 99 \%\right)$, hydrogen peroxide $\left(\mathrm{H}_{2} \mathrm{O}_{2}, 30 \%\right)$, and $n$-hexane were provided by Aladdin Industrial Inc. Polysulfone (PSf) p-3500 ( $\mathrm{MW}=35,000)$, polyethylene glycol (PEG), and dimethylformamide (DMF) were purchased from Sigma-Aldrich. None of the chemicals used had undergone purification.

2.2. Preparation of GO. The preparation of GO was carried out using modified Hummer's method [34-36]. In a typical synthesis, $1.0 \mathrm{~g}$ of graphite powder was added to $2.5 \mathrm{~g}$ of $\mathrm{NaNO}_{3}$ and $100 \mathrm{~mL}$ of concentrated $\mathrm{H}_{2} \mathrm{SO}_{4}$ while stirring. Following on, $3.0 \mathrm{~g}$ of $\mathrm{KMnO}_{4}$ was added gradually to this mixture at $10^{\circ} \mathrm{C}$ while stirring for $2 \mathrm{~h}$. The resulting mixture was added to $100 \mathrm{~mL}$ of distilled water and then heated to $98^{\circ} \mathrm{C}$. The obtained mixture was continuously stirred for $2 \mathrm{~h}$. Then, $10 \mathrm{~mL}$ of $\mathrm{H}_{2} \mathrm{O}_{2}$ was then added to the mixture while stirring for $2 \mathrm{~h}$. The color of the mixture changed to bright yellow. Finally, the mixture was filtered and washed with a $5 \% \mathrm{HCl}$ aqueous solution to remove metal ions, followed by distilled water for the removal of the acid. The resulting solid, with a brown-black color, was separated by ultrasonic treatment in water and then dried at $60^{\circ} \mathrm{C}$ for $12 \mathrm{~h}$.

\subsection{Preparation of PSf and PSf/GO Membrane. A PSf/GO} membrane was formed according to the procedure set out in $[37,38]$. The casting solution contained PSf $=15 \mathrm{wt} . \%$, $\mathrm{DMF}=85 \mathrm{wt} . \%$, and GO $=(0 ; 2 \mathrm{wt} . \% \mathrm{PSf})$. Firstly, the determined amount of GO was dispersed in an DMF solvent, which was ultrasonically vibrated for $1 \mathrm{~h}$, and then stirred continuously for approximately $24 \mathrm{~h}$, at room temperature, following which a homogenous solution was obtained. Then, PSf was added to the GO/DMF mixture and stirred continuously at the rate of $400 \mathrm{rpm}$ for $24 \mathrm{~h}$ at $60^{\circ} \mathrm{C}$; thus, a homogenous membrane folding solution was obtained. This solution was dripped onto the $15 \mathrm{~cm}$ diameter glass substrate of the spin coater at the rotation speed of $200 \mathrm{rpm}$. Under the effect of the centrifugal force, the solution spread uniformly on the substrate and formed a thin membrane. The glass substrate was placed into a deionised (DI) water bath and allowed to settle for $10 \mathrm{~min}$ to ensure the completion of the phase inversion process. Finally, synthetic membranes were exfoliated and washed several times with deionised water to remove the excess solvent; the obtained membranes were denoted as PSf and PSf/GO.

\subsection{Preparation of PSf/GO- $\mathrm{Al}_{2} \mathrm{O}_{3}$ Nanocomposite Membrane}

2.4.1. Preparation of $\mathrm{Al}_{2} \mathrm{O}_{3}$ and $\mathrm{GO}-\mathrm{Al}_{2} \mathrm{O}_{3}$ Nanoparticles. $\mathrm{GO}-\mathrm{Al}_{2} \mathrm{O}_{3}$ nanoparticles were synthesised through a onepot hydrothermal procedure. In brief, $0.855 \mathrm{~g}$ of $\mathrm{Al}_{2}\left(\mathrm{SO}_{4}\right)_{3}$ was dissolved with a $5 \mathrm{M} \mathrm{NaOH}$ solution. Subsequently, $0.01 \mathrm{~g}$ of PEG was added to this solution as a dispersant. After $10 \mathrm{~min}$ of homogenisation, a determined amount of GO (0.0, 
$1.0 \mathrm{~g}$ ) was added and stirred for $1 \mathrm{~h}$. The $\mathrm{pH}$ of the mixture was adjusted to 6.0 by using $1 \mathrm{M} \mathrm{H}_{2} \mathrm{SO}_{4}$ while stirring vigorously. Finally, the gel was formed and transferred into a Teflon autoclave for hydrothermal synthesis at $90^{\circ} \mathrm{C}$ for $2 \mathrm{~h}$. The suspension was then filtered, washed with deionised water, and oven-dried at $110^{\circ} \mathrm{C}$ overnight. Subsequently, calcination was undertaken at $550^{\circ} \mathrm{C}$ for $5 \mathrm{~h}$ to obtain $\mathrm{Al}_{2} \mathrm{O}_{3}$ and $\mathrm{GO}$ $\mathrm{Al}_{2} \mathrm{O}_{3}$ nanoparticles.

2.4.2. Preparation of $\mathrm{PSf} / \mathrm{GO}-\mathrm{Al}_{2} \mathrm{O}_{3}$ Nanocomposite Membrane. A PSf/GO- $\mathrm{Al}_{2} \mathrm{O}_{3}$ nanocomposite membrane was prepared according to the following procedure: GO$\mathrm{Al}_{2} \mathrm{O}_{3}$ was exfoliated by ultrasonication in a DMF solution. Therefore, $\mathrm{GO}-\mathrm{Al}_{2} \mathrm{O}_{3}$ nanoparticles were dispersed in a DMF solution containing PSf (15wt.\% PSf and $85 \mathrm{wt} . \%$ DMF) to obtain different concentrations of $\mathrm{GO}-\mathrm{Al}_{2} \mathrm{O}_{3}(0.5$, $1.0,1.5$, and $2 \%$ by weight of PSf). After stirring for $24 \mathrm{~h}$ at $60^{\circ} \mathrm{C}$, the solution was kept overnight at room temperature, following which it was sonicated for $1 \mathrm{~h}$ to remove the bubbles. The solution was casted on a rotating glass plate at $200 \mathrm{rpm}$. The glass plate was immersed in a deionised (DI) water basin and allowed to settle for $10 \mathrm{~min}$ to ensure the completion of the phase inversion. Finally, the membrane was exfoliated and washed several times with deionised water to remove the excess solvent. The PSf/GO- $\mathrm{Al}_{2} \mathrm{O}_{3}$ membranes thus prepared had various contents of $\mathrm{GO}-\mathrm{Al}_{2} \mathrm{O}_{3}$ with respect to PSf: $0.5,1.0,1.5$, and $2.0 \mathrm{wt} . \%$.

2.5. Preparation of Oil-in-Water Emulsion. An emulsion of diesel oil (DO) in water at a concentration of $1500 \mathrm{mg} / \mathrm{L}$ was prepared by mixing the determined amount of diesel oil into a solution containing water and sodium dodecyl sulfate (SDS) as an emulsifier. The mixture was stirred at $4000 \mathrm{rpm}$ in a blender for $1 \mathrm{~h}$. The emulsion was stable for $24 \mathrm{~h}$ at room temperature.

2.6. Separation of Oil-in-Water Emulsion. Membrane separation tests were performed in a terminal filtration system, including $200 \mathrm{~cm}^{3}$ stainless steel cylindrical cells and a paddle impeller; and the working pressure in all the experiments was 0.87 bar. The volume of the filtrate was collected every $5 \mathrm{~min}$, and the average throughput was calculated after $90 \mathrm{~min}$ of filtration. In all the experiments, the membrane cells were carefully washed with deionised water before and after use. The membrane was reused after filtration, soaked in an $n$-hexane solvent, and dried in an oven overnight at $60^{\circ} \mathrm{C}$ so that it could be used for subsequent filtration.

The ability to separate oil from the water/oil emulsion of the membrane was determined through the oil rejection $(R)$ and permeate flux $(J)$. The oil rejection percentage $(R)$ was calculated using the following equation:

$$
\% R=\frac{C_{\mathrm{f}}-C_{\mathrm{p}}}{C_{\mathrm{f}}} \times 100,
$$

where $C_{\mathrm{f}}$ and $C_{\mathrm{p}}$ are the concentrations of oil in the feed and the permeate solution, respectively.

The permeate flux $\left(J, \mathrm{~L} / \mathrm{m}^{2} \cdot \mathrm{h} \cdot \mathrm{bar}\right)$ was evaluated using $J=V /(S \times t \times P)$, where $V, S, t$, and $P$ are the volume of the permeated filtrate $(\mathrm{L})$, effective membrane area $\left(\mathrm{m}^{2}\right)$, time duration ( $\mathrm{min})$, and pressure of the experiments (0.87 bar).

The irreversible fouling coefficient $\mathrm{FR}_{\mathrm{w}}$ was used to evaluate the ability of the membrane to clean and restore its permeate flux through washing, by using the following equation:

$$
\mathrm{FR}_{\mathrm{w}}=\frac{J_{\mathrm{wo}}-J_{\mathrm{w}}}{J_{\mathrm{wo}}} \times 100(\%),
$$

where $J_{\mathrm{wo}}$ and $J_{\mathrm{w}}$ are the water permeability through the membrane before and after the emulsion filter. $J_{\mathrm{w}}$ was determined through measuring the volume of pure water transported through the membrane over a period of time $t$, calculated using Equation (2). The lower the $\mathrm{FR}_{\mathrm{w}}$ value was, the higher the antifouling ability was.

2.7. Membrane Characterisations. The structure and the surface morphology of the membranes were observed with scanning electron microscopy (SEM) using an S-4800 microscope, operating at an accelerating voltage of $200 \mathrm{kV}$. An energy-dispersive X-ray spectroscopy (EDX) analysis was conducted to determine the presence of the elements of the samples by using S-4800 Hitachi equipped with SEM. Fourier transform infrared (FT-IR) spectroscopy was conducted using a Shimadzu IRPrestige-21 spectrometer, and a transmittance between $400 \mathrm{~cm}^{-1}$ and $4000 \mathrm{~cm}^{-1}$ was observed. A thermogravimetric analysis (TG/DTA) of the membranes was carried out using a DTG- $60 \mathrm{H}$ thermal analyser. The thermogram was recorded at room temperature and $800^{\circ} \mathrm{C}$ at a heating rate of $10^{\circ} \mathrm{C} / \mathrm{min}$, under a $\mathrm{N}_{2}$ atmosphere with a flow rate of $10 \mathrm{~mL} / \mathrm{min}$. The Brunauer-Emmett-Teller (BET) surface areas of the membranes were calculated by employing $\mathrm{N}_{2}$ at $77 \mathrm{~K}$, with an Automated Sorptometer BET 201-A, USA. A water contact angle measurement was used to calculate the moisture content of the unblended and blended membranes via CAM 101/KSV-InstrumentsFinland, which was employed to capture ionised water drops located on the dry surface of the membrane at $25^{\circ} \mathrm{C}$.

\section{Results and Discussion}

3.1. Morphological and Structural Characterisation of Membranes. Figure 1 shows the XRD diffraction for GO and $\mathrm{GO}-\mathrm{Al}_{2} \mathrm{O}_{3}$ samples. The diffraction peak around $11.5^{\circ}$ was related to the (001) interlayer structure of GO sheets. For $\mathrm{GO}-\mathrm{Al}_{2} \mathrm{O}_{3}$, the diffraction peak at $33.5,45.6$, and $56.4^{\circ}$ could be indexed to the $\gamma-\mathrm{Al}_{2} \mathrm{O}_{3}$ structure (ICDD reference pattern 00-010-0425), while no (001) diffraction of GO was observed, thus indicating that the peak of GO (001) may be overlapped by the peak of $\gamma-\mathrm{Al}_{2} \mathrm{O}_{3}$. This revealed that the preparation of $\mathrm{GO}-\mathrm{Al}_{2} \mathrm{O}_{3}$ nanoparticles was successful.

The SEM images (Figure 2) of pristine PSf, PSf/GO, and $\mathrm{PSf} / \mathrm{GO}-\mathrm{Al}_{2} \mathrm{O}_{3}-1.5$ membranes show the formation of pores with a dense outer surface (exhibited in Figures 1 and 2(a). As shown in the cross-sectional images, the finger-like pores appeared and increased with the doping of $\mathrm{GO}$ and $\mathrm{GO}$ $\mathrm{Al}_{2} \mathrm{O}_{3}$. In particular, the thicknesses of the PSf, PSf/GO, and PSf/GO- $\mathrm{Al}_{2} \mathrm{O}_{3}-1.5$ membranes were 27,30 , and $65 \mu \mathrm{m}$, 
respectively. The increase in the interlayer spacing of the membranes was due to the insertion of the GO and GO$\mathrm{Al}_{2} \mathrm{O}_{3}$ nanoparticles. Furthermore, with the modification of $\mathrm{GO}$ and $\mathrm{GO}-\mathrm{Al}_{2} \mathrm{O}_{3}$ in the pristine PSf substrate, the outer surface became denser than that of the pristine PSf, and the porosity density increased on the membrane surface. It could be speculated that the viscosity of the solution increased by blending the nanoparticles in the PSf membranes; this led to increased condensation and thus an increase in the surface density, which can give rise to the narrowing of pore channels [39].

In order to further evaluate the surface area and the total pore volume of the unmodified PSf pristine and modified PSf/GO- $\mathrm{Al}_{2} \mathrm{O}_{3}-1.5$ membranes, the $\mathrm{N}_{2}$ adsorptiondesorption isotherm was performed. The obtained results showed that the surface area increased from $2.29 \mathrm{~m}^{2} / \mathrm{g}$ to $3.56 \mathrm{~m}^{2} / \mathrm{g}$ for the PSf and PSf/GO- $\mathrm{Al}_{2} \mathrm{O}_{3}-1.5$ membranes. The average pore size of the PSf/GO- $\mathrm{Al}_{2} \mathrm{O}_{3}-1.5$ membrane was greater $(2.75 \mathrm{~nm})$ than that of the pristine PSf membrane $(1.82 \mathrm{~nm})$. Meanwhile, the pore volume is $0.00073 \mathrm{~cm}^{3} / \mathrm{g}$ for $\mathrm{PSf} / \mathrm{GO}-\mathrm{Al}_{2} \mathrm{O}_{3}-1.5$ and $0.00074 \mathrm{~cm}^{3} / \mathrm{g}$ for PSf without any significant change. This result indicated that the increase in the surface area and the pore diameter of PSf/GO- $\mathrm{Al}_{2} \mathrm{O}_{3}$ 1.5 was attributed to the insertion of $\mathrm{GO}-\mathrm{Al}_{2} \mathrm{O}_{3}$ nanoparticles into the layers on the pristine PSf membrane surface; this was also consistent with the results obtained from the SEM images.

To evaluate the thermal durability of the PSf membrane before and after the blending of $\mathrm{GO}-\mathrm{Al}_{2} \mathrm{O}_{3}$, the thermogravimetric analysis was used and is presented in Figure 3. The TG/DTA for the PSf/GO- $\mathrm{Al}_{2} \mathrm{O}_{3}-1.5$ membrane showed that in the temperature range of $533.86^{\circ} \mathrm{C}$, the membrane began to decompose, and the lost weight was $1.553 \mathrm{mg}$, which corresponds to $51.80 \%$. At $800^{\circ} \mathrm{C}$, the membrane was decomposed almost completely. The TG/DTA graph of the PSf membrane, with weight loss of $2.895 \mathrm{mg}$ at $525.8^{\circ} \mathrm{C}$, corresponded to $48.62 \%$. When the temperature reached $700^{\circ} \mathrm{C}$, the decomposition was mostly complete. These results showed that after being modified by $\mathrm{GO}-\mathrm{Al}_{2} \mathrm{O}_{3}$, the PSf membrane had a higher decomposition temperature than the pristine PSf membrane, indicating that the presence of $\mathrm{GO}$ and $\mathrm{Al}_{2} \mathrm{O}_{3}$ increased the thermal durability of the membrane.

The samples of the $\mathrm{Al}_{2} \mathrm{O}_{3}, \mathrm{GO}-\mathrm{Al}_{2} \mathrm{O}_{3}$, and PSf/GO$\mathrm{Al}_{2} \mathrm{O}_{3}-1.5$ membranes were recorded by the FT-IR spectra for the inspection of the functional groups. The corresponding results are shown in Figure 4.

These FT-IR spectra (Figure 4) clearly show the characteristic peaks around $3400 \mathrm{~cm}^{-1}$ from the stretching vibration of the O-H bond, which confirmed the formation of a hydrophilic group on the surface of the modified membrane. The peak at $1713 \mathrm{~cm}^{-1}$ was attributed to the carboxyl functional group $(-\mathrm{COOH})$, while the peak at around $1619 \mathrm{~cm}^{-1}$ was assigned to the epoxy bond as well as the bending vibration bands of $\mathrm{OH}$ due to the adsorption of water into the GO matrix [40]. For the PSf/GO- $\mathrm{Al}_{2} \mathrm{O}_{3}$ membrane, the peaks at $1100 \mathrm{~cm}^{-1}$ represented the symmetric stretching vibration of $\mathrm{O}=\mathrm{S}=\mathrm{O}$, whereas the peak at around $1380 \mathrm{~cm}^{-1}$ was related to the $\mathrm{O}=\mathrm{S}=\mathrm{O}$ asymmetric stretching. The band at around

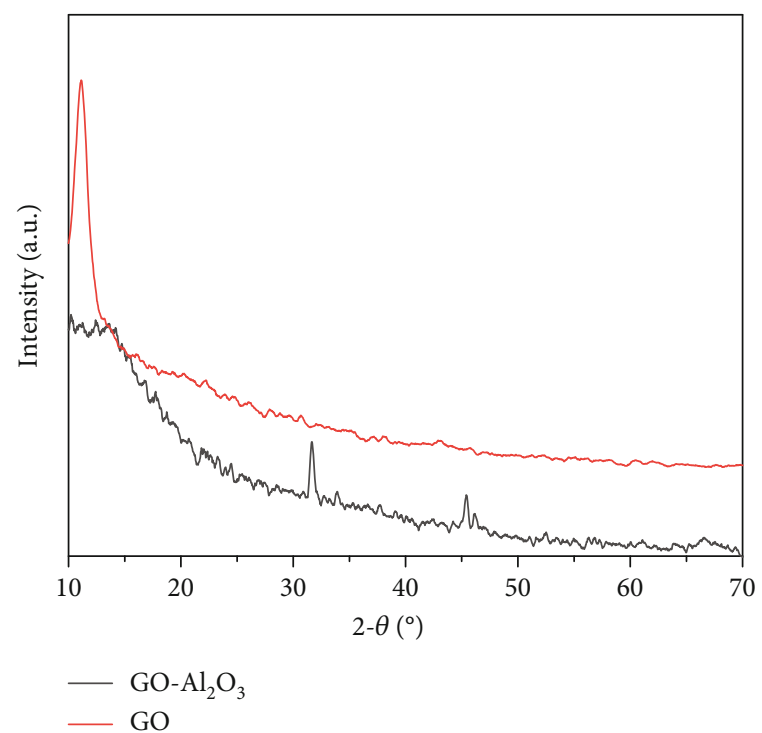

FIgURE 1: XRD patterns of $\mathrm{GO}$ and $\mathrm{GO}-\mathrm{Al}_{2} \mathrm{O}_{3}$ samples.

$1487 \mathrm{~cm}^{-1}$ was assigned to a specific phenyl vibration. The bands at around $1238 \mathrm{~cm}^{-1}$ and $1040 \mathrm{~cm}^{-1}$ corresponded to the asymmetric and symmetric stretching vibrations of the C-O-C group, respectively. Moreover, the peak at the wave number of $2900 \mathrm{~cm}^{-1}$ was attributed to the stretching vibration of the $\mathrm{C}-\mathrm{H}$ bond $[41,42]$. Upon the insertion of $\mathrm{GO}-\mathrm{Al}_{2} \mathrm{O}_{3}$ into the PSf matrix, the spectral range from $1370 \mathrm{~cm}^{-1}$ to $450 \mathrm{~cm}^{-1}$ was assigned to the absorption bands related to the Al-O type bonds [43].

Figure 5 shows the spectrograms obtained from the EDX analysis of the prepared membranes. The primary elements, namely, carbon, oxygen, sulphur, and aluminium, were analysed. A relatively low sulphur content was found in the pristine PSf, PSf/GO, and PSf/GO- $\mathrm{Al}_{2} \mathrm{O}_{3}-1.5$ membranes, i.e., $4.56 \mathrm{wt} . \%, 5.95 \mathrm{wt} . \%$, and $3.44 \mathrm{wt} . \%$, respectively. When GO was incorporated into the pristine PSf membrane, the carbon content increased dramatically to $5.95 \mathrm{wt} . \%$. In contrast, the sulphur content of the PSf/GO- $\mathrm{Al}_{2} \mathrm{O}_{3}-1.5$ membrane decreased back to $3.44 \mathrm{wt} . \%$, and the aluminium content was 0.19 wt.\%. Figure 5 also shows the SEM images illustrating the presence of multiple nodules on the membrane surface and indicating the successful embedment of GO- $\mathrm{Al}_{2} \mathrm{O}_{3}$ throughout the PSf structure.

3.2. Water Contact Angle of the Membrane. The change in the water flow of the PSf membrane was attributed to the hydrophilicity surface of the modified membrane; this was evaluated by examining the water contact angle. As shown in Figure 6, the water contact angle of the membrane which was modified by inserting $\mathrm{GO}$ and $\mathrm{GO}-\mathrm{Al}_{2} \mathrm{O}_{3}$ into the PSf matrix changed as compared to that of the pristine PSf membrane. In particular, the water contact angle of the PSf/GO$\mathrm{Al}_{2} \mathrm{O}_{3}-1.5$ membrane $\left(66.0 \pm 1.2^{\circ}\right)$ exhibited a significant decrease compared with that of the PSf/GO $\left(76.2 \pm 0.04^{\circ}\right)$ sample and the PSf membrane $\left(83.4 \pm 0.09^{\circ}\right)$ (Table 1). The improving hydrophilicity was mainly attributed to the 

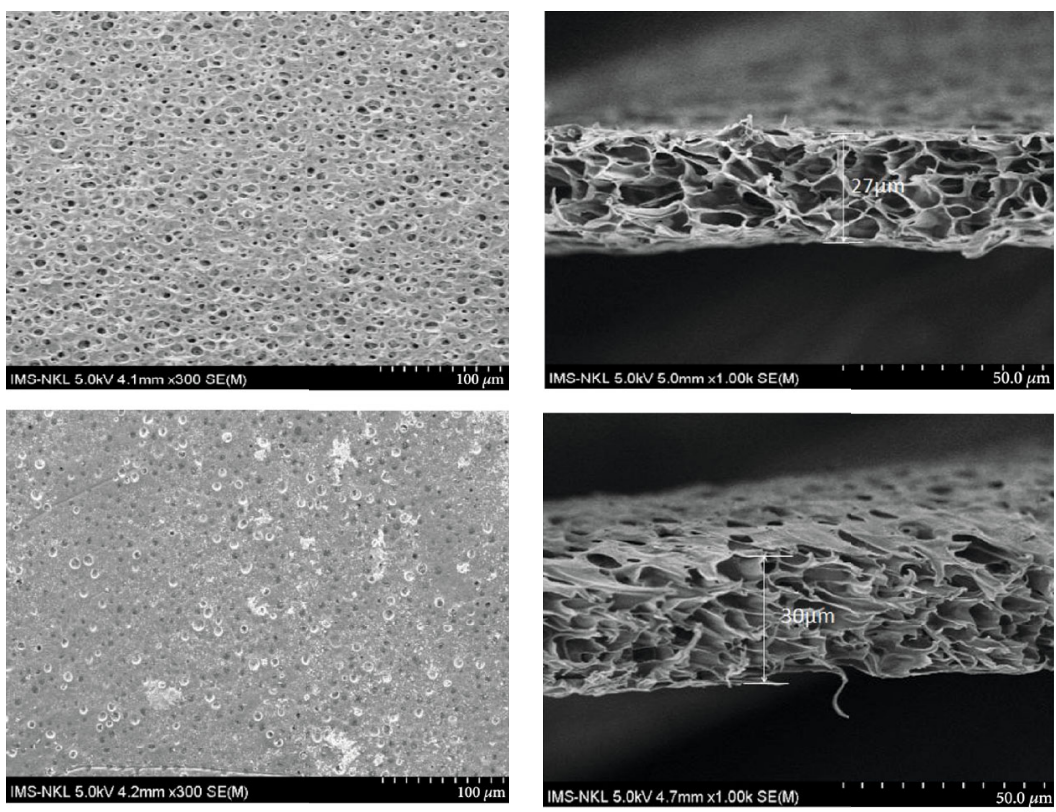

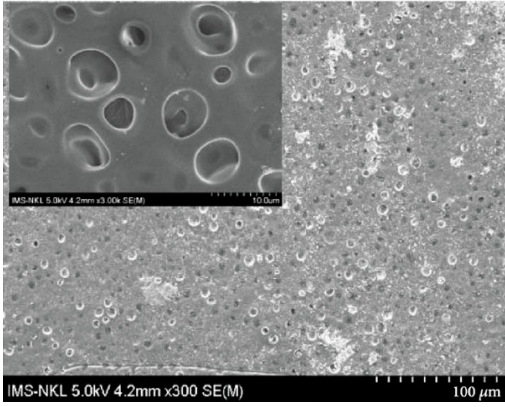

(a)

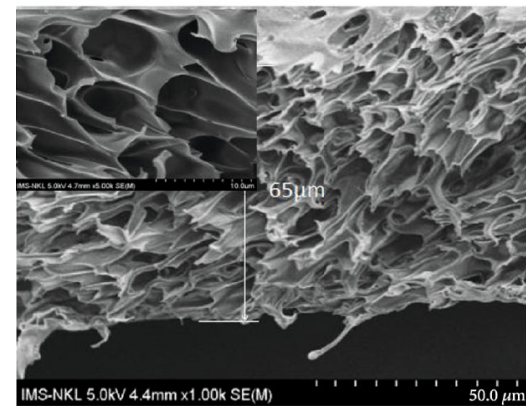

(b)

FIGURE 2: SEM images of the surface (a) and the cross-sectional images (b) of PSf, PSf/GO, and PSf/GO- $\mathrm{Al}_{2} \mathrm{O}_{3}-1.5$ membranes (inset: the high magnification images).

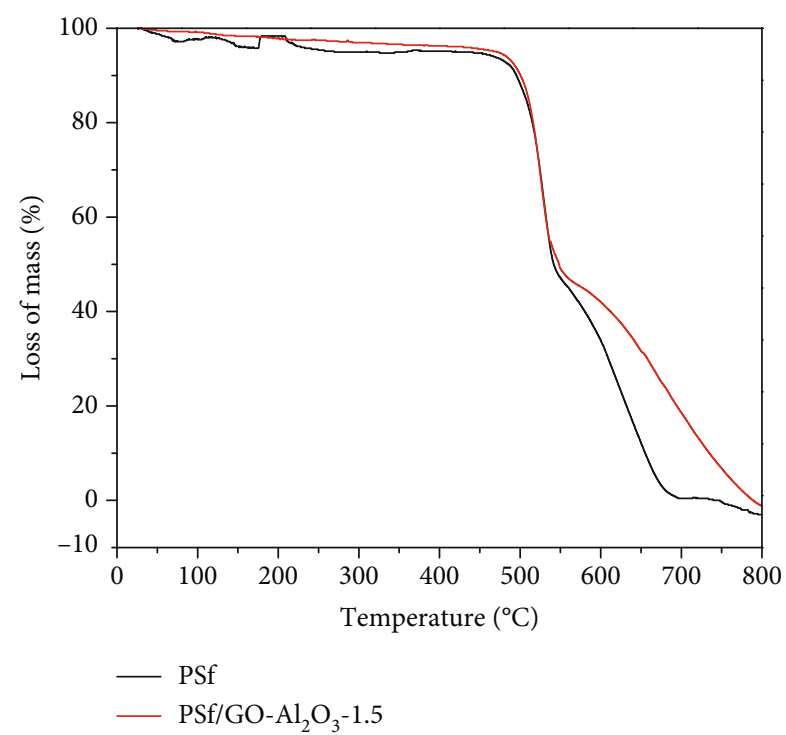

FIGURE 3: TGA and DTA curves of PSf and PSf/GO- $\mathrm{Al}_{2} \mathrm{O}_{3}-1.5$ membranes.

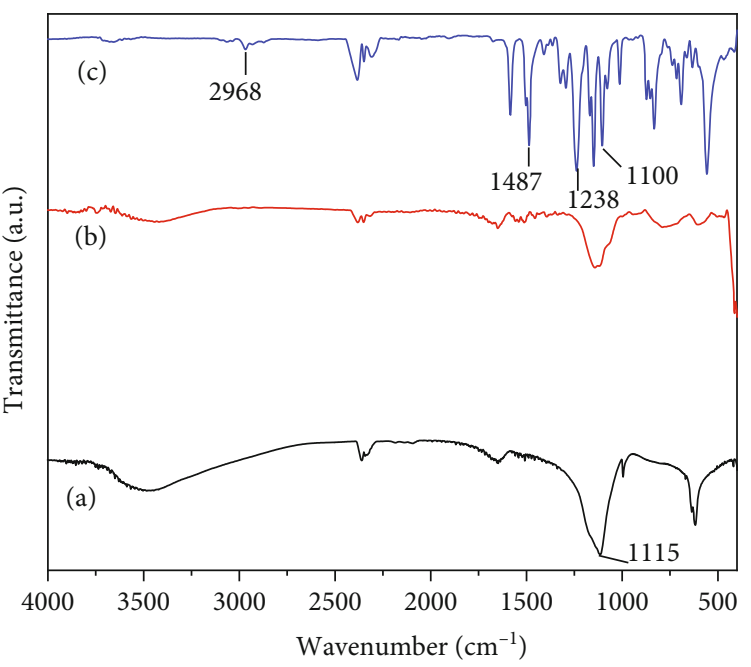

FIgURE 4: FT-IR spectra of (a) $\mathrm{Al}_{2} \mathrm{O}_{3}$, (b) $\mathrm{GO}-\mathrm{Al}_{2} \mathrm{O}_{3}$, and (c) PSf/GO- $\mathrm{Al}_{2} \mathrm{O}_{3}-1.5$ membranes. 


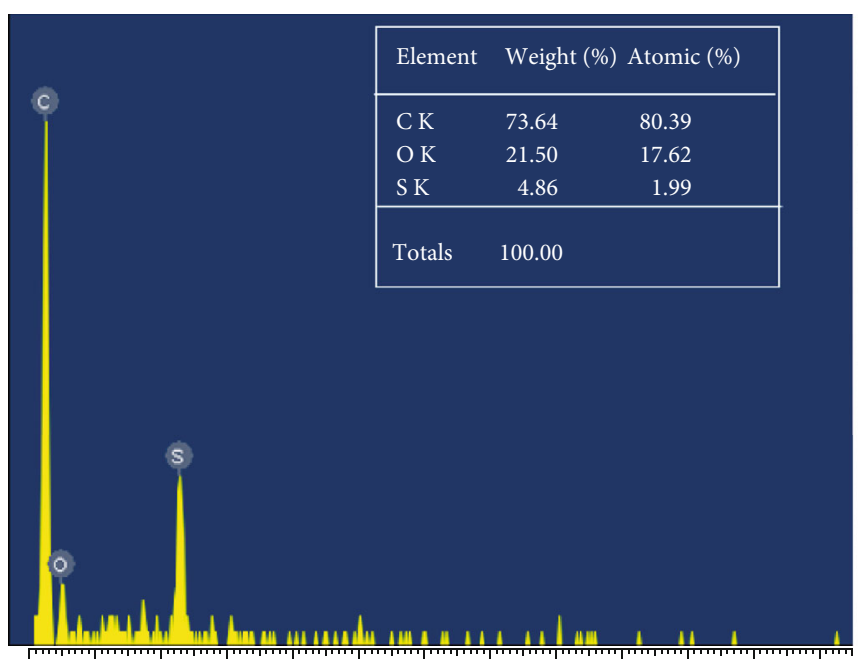

(a)

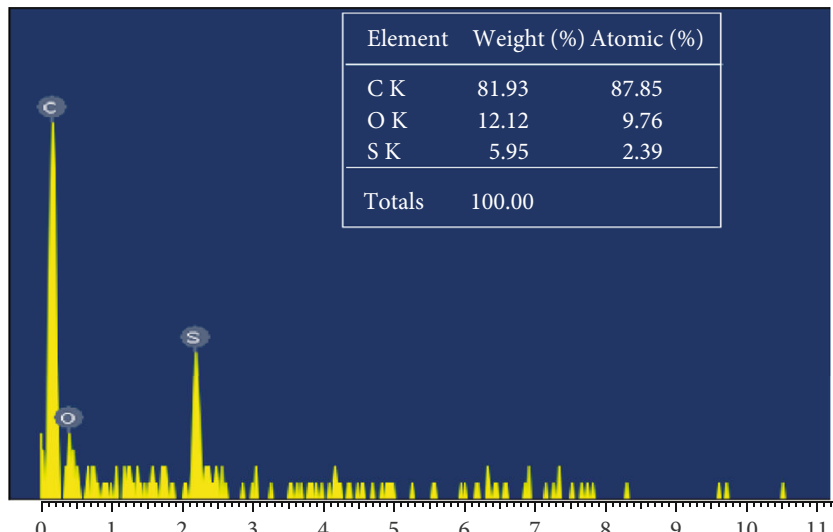

(b)

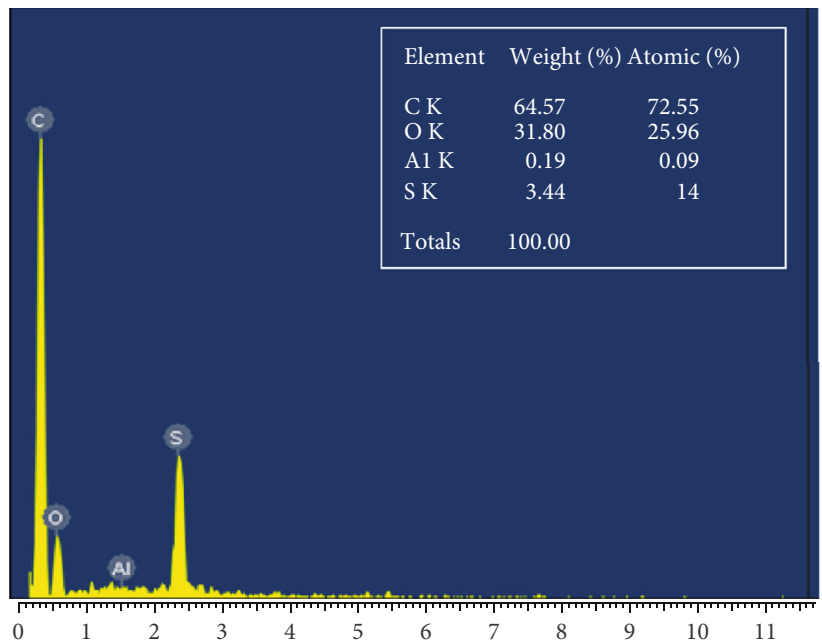

(c)

FIGURE 5: Spectrogram of energy-dispersive X-ray spectroscopy (EDX) of membrane samples: (a) pristine PSf membrane, (b) PSf/GO membrane, and (c) PSf/GO- $\mathrm{Al}_{2} \mathrm{O}_{3}-1.5$ membrane.

presence of hydrophilic oxygen-containing functional groups such as carboxyl and hydroxyl groups existing in GO and $\mathrm{Al}_{2} \mathrm{O}_{3}$ [20].
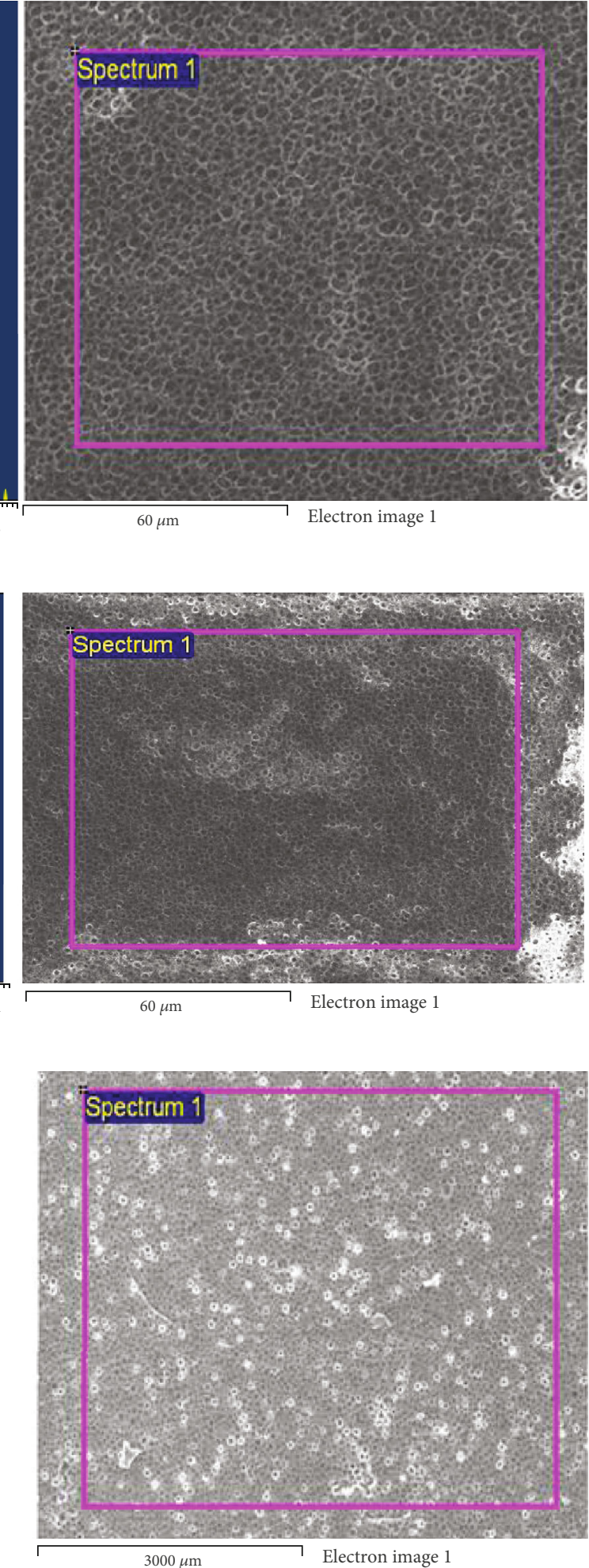

$60 \mu \mathrm{m}$

Electron image 

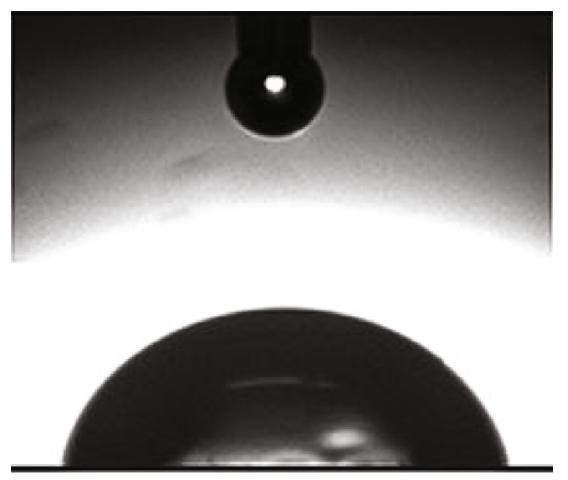

PSf membrane

(a)

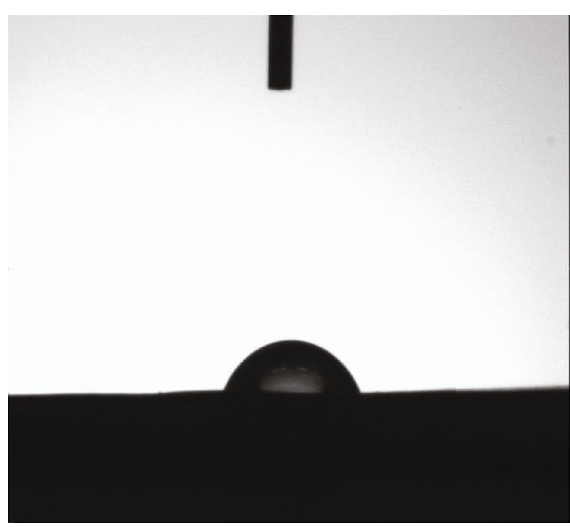

GO

(c)
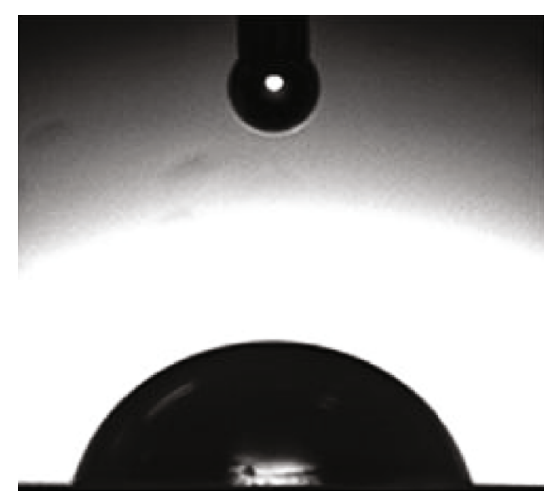

PSf/GO membrane

(b)

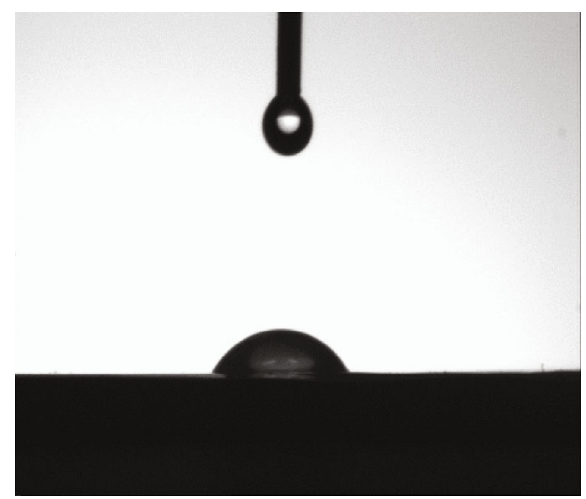

PSf/GO-Al2O3-1.5 membrane

(d)

FIGURE 6: Water contact angle images of (a) PSf, (b) GO, (c) PSf/GO, and (d) PSf/GO- $\mathrm{Al}_{2} \mathrm{O}_{3}-1.5$ membranes.

TABLE 1: Water contact angle values of PSf, GO, PSf/GO, and PSf/GO- $\mathrm{Al}_{2} \mathrm{O}_{3}-1.5$ membranes.

\begin{tabular}{lcccc}
\hline Membranes & PSf & GO & PSf/GO & $\begin{array}{c}\text { PSf/GO- } \\
\mathrm{Al}_{2} \mathrm{O}_{3}-1.5\end{array}$ \\
\hline WCA $\left(^{\circ}\right)$ & $83.4 \pm 0.09$ & $64.5 \pm 0.03$ & $76.2 \pm 0.04$ & $66.0 \pm 1.2$ \\
\hline
\end{tabular}

Values of three replicates are expressed as the mean \pm SD (standard deviation).

0.87 bar; the separation time was more than 90 min. The concentration of the oil/water emulsion of the feed solution was $450 \mathrm{mg} / \mathrm{L}$. The oil rejection and the permeate flux of the PSf and PSf/GO membranes versus those of the PSf/GO- $\mathrm{Al}_{2} \mathrm{O}_{3}$ 1.5 membranes are shown in Figures 7 and 8, respectively.

The obtained results showed that the modified membrane of $\mathrm{PSf} / \mathrm{GO}-\mathrm{Al}_{2} \mathrm{O}_{3}-1.5$ had a higher permeate flux and rejection than the PSf and PSf/GO membranes. The rejection of the PSf membrane was only $47 \%$, while the PSf membrane modified by GO exhibited an improved rejection $(60 \%)$ and the $\mathrm{PSf} / \mathrm{GO}-\mathrm{Al}_{2} \mathrm{O}_{3}-1.5$ membrane had a high rejection of $74 \%$.

As can be seen in Figure 8, the permeate flux of the PSf/GO- $\mathrm{Al}_{2} \mathrm{O}_{3}-1.5$ membrane was also higher than that of the PSf/GO and PSf membranes. The permeate flux of the PSf, PSf/GO, and PSf/GO- $\mathrm{Al}_{2} \mathrm{O}_{3}-1.5$ membranes was 9.58, 9.82, and $16.28 \mathrm{~L} / \mathrm{m}^{2} \cdot \mathrm{h} \cdot$ bar after $30 \mathrm{~min}$, respectively. The

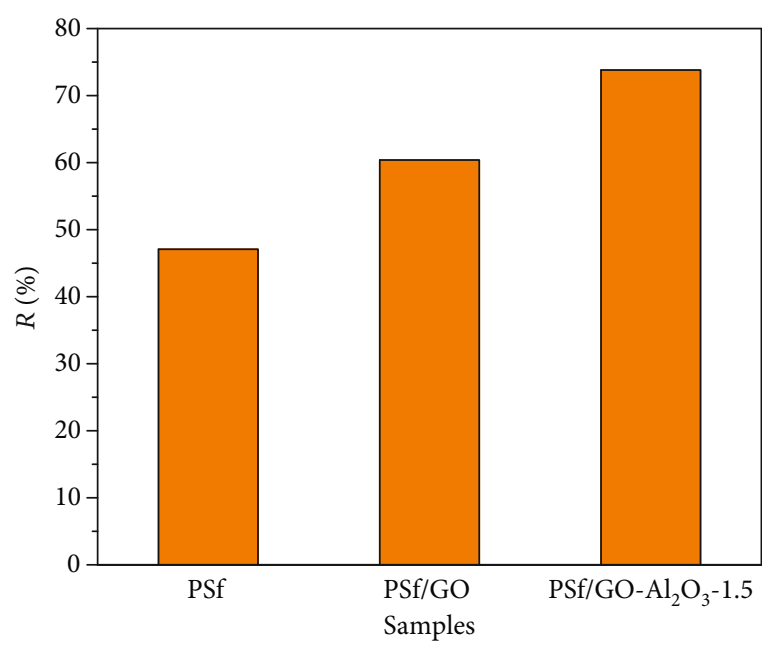

FIgURE 7: Rejection of the PSf, PSf/GO, and PSf/GO- $\mathrm{Al}_{2} \mathrm{O}_{3}-1.5$ membranes (test conditions: operating pressure of 0.87 bar at ambient temperature and feed emulsion: $450 \mathrm{mg} / \mathrm{L}$ ).

increase in the flux by the $\mathrm{GO}-\mathrm{Al}_{2} \mathrm{O}_{3}$ coating into the pristine SPf membrane pore surface could result in the formation of $\mathrm{Al}-\mathrm{O}-\mathrm{C}$ bond between hydroxyl groups on the GO surface and $\mathrm{Al}_{2} \mathrm{O}_{3}$ [24]. In addition, the enhancement of the permeate flux could be also attributed to the surface of $\mathrm{Al}_{2} \mathrm{O}_{3}$ 


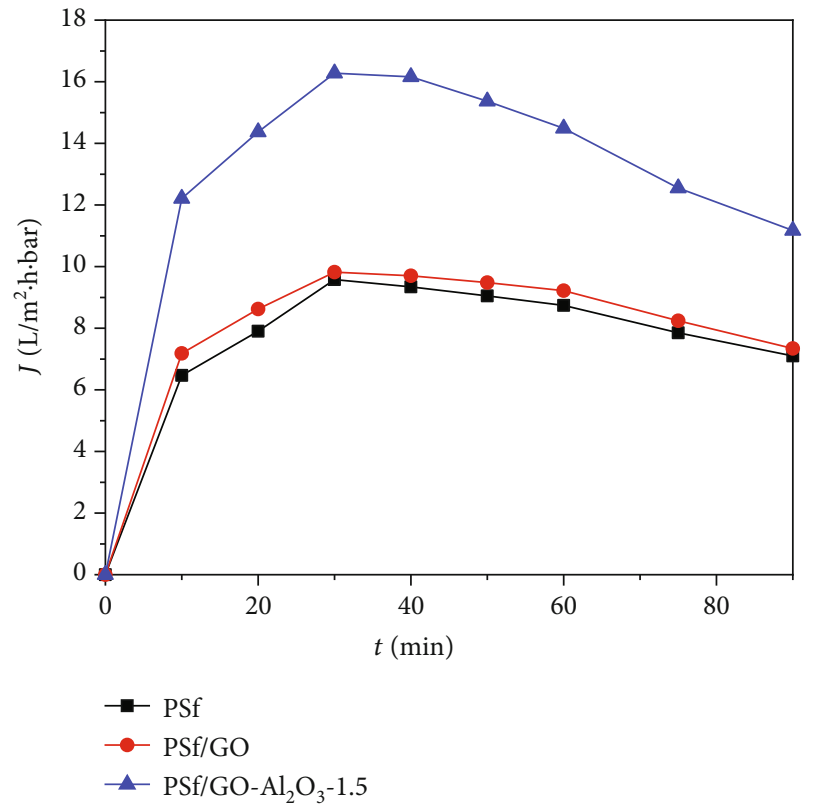

Figure 8: Permeate flux of the PSf, PSf/GO, and PSf/GO- $\mathrm{Al}_{2} \mathrm{O}_{3}-1.5$ membranes over time (test conditions: operating pressure of 0.87 bar at ambient temperature and feed emulsion: $450 \mathrm{mg} / \mathrm{L}$ ).

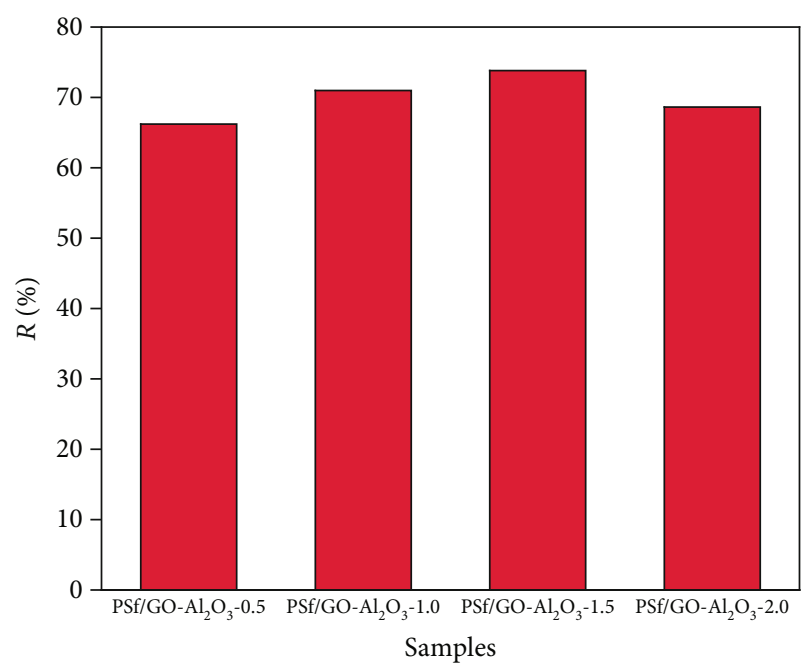

FIGURE 9: Rejection of PSf/GO- $\mathrm{Al}_{2} \mathrm{O}_{3}-0.5$, PSf/GO- $\mathrm{Al}_{2} \mathrm{O}_{3}-1.0$, PSf/GO- $\mathrm{Al}_{2} \mathrm{O}_{3}-1.5$, and PSf/GO- $\mathrm{Al}_{2} \mathrm{O}_{3}-2.0$ membranes (test conditions: operating pressure of 0.87 bar at ambient temperature, feed emulsion: $450 \mathrm{mg} / \mathrm{L}$, and $\mathrm{pH}=7$ ).

having many different types of interactions during the oil rejection from the oil/water emulsion. Thus, modifying the PSf membrane via GO- $\mathrm{Al}_{2} \mathrm{O}_{3}$ not only increased the specific surface area (from $2.28 \mathrm{~m}^{2} \mathrm{~g}^{-1}$ to $3.56 \mathrm{~m}^{2} \mathrm{~g}^{-1}$ ) but also increased the permeability of the pristine PSf membrane.

As shown in Figure 8, when the oil rejection time increased from 0 to $30 \mathrm{~min}$, the permeate flux increased obviously, and then, the permeate flux decreased from $30 \mathrm{~min}$ to $90 \mathrm{~min}$, which could be attributed to the fouling of the membrane pore compaction $[42,44,45]$. On the basis of these results, the PSf/GO- $\mathrm{Al}_{2} \mathrm{O}_{3}-1.5$ membrane was selected for

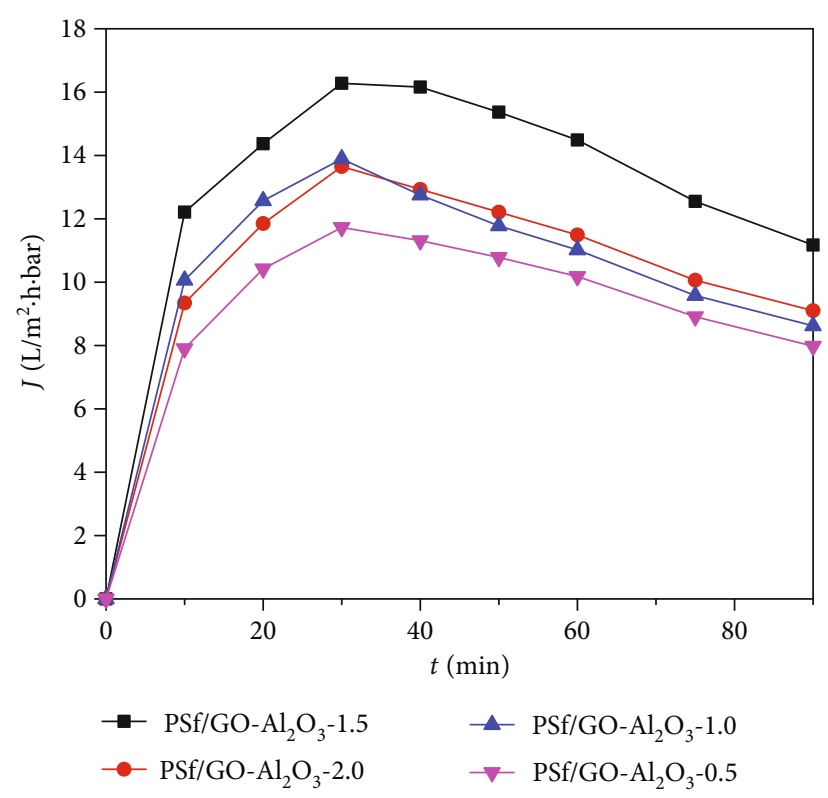

Figure 10: Permeate flux of PSf/GO- $\mathrm{Al}_{2} \mathrm{O}_{3}-0.5$, PSf/GO- $\mathrm{Al}_{2} \mathrm{O}_{3}-1.0$, PSf/GO- $\mathrm{Al}_{2} \mathrm{O}_{3}-1.5$, and PSf/GO- $\mathrm{Al}_{2} \mathrm{O}_{3}-2.0$ membranes (test conditions: operating pressure of 0.87 bar at ambient temperature, feed emulsion: $450 \mathrm{mg} / \mathrm{L}$, and $\mathrm{pH}=7$ ).

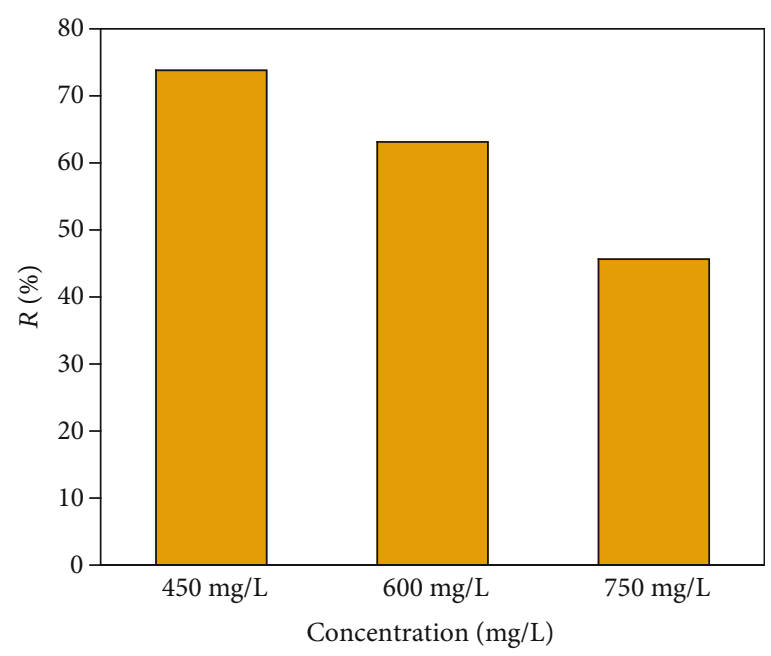

FIgURE 11: Rejection of PSf/GO- $\mathrm{Al}_{2} \mathrm{O}_{3}-1.5$ membrane with different emulsion concentrations (test conditions: operating pressure of 0.87 bar at ambient temperature and $\mathrm{pH}=7$ ).

further experiments on oil removal from an oil/water emulsion.

\subsubsection{Influence of Factors on Oil Rejection of Membranes}

(1) Effect of $\mathrm{GO}-\mathrm{Al}_{2} \mathrm{O}_{3}$ Nanomaterials on the Performance of PSf Membrane. The effects of using nanoparticleincorporated substrates on the SPf membranes with respect to the permeate flux and the oil rejection were evaluated using the experimental setup (operating pressure of 0.87 bar at ambient temperature, feed emulsion of $450 \mathrm{ppm}$, and 


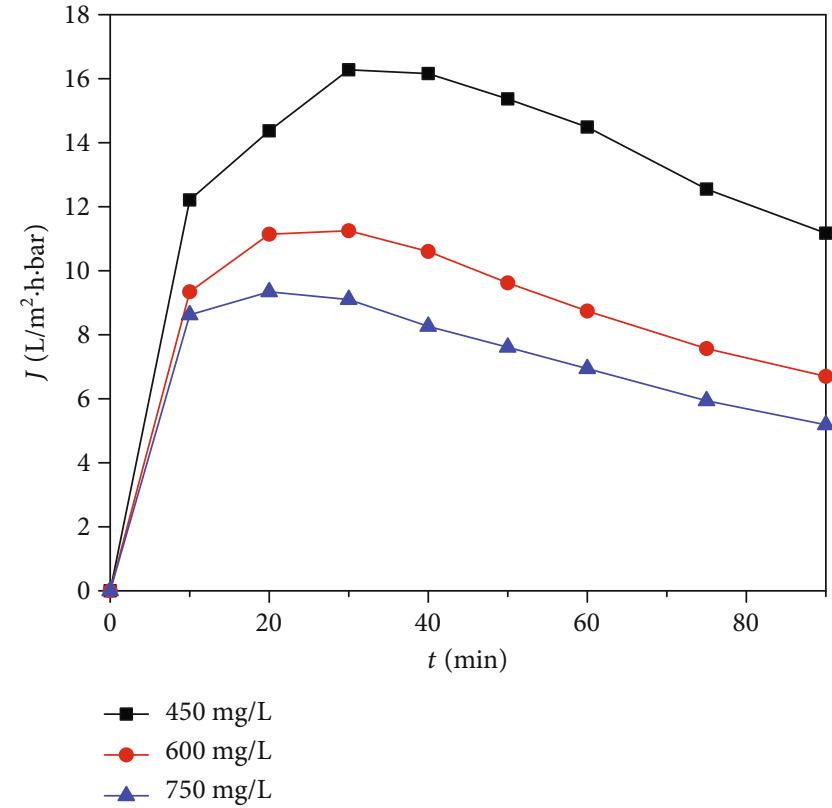

Figure 12: Permeate flux of PSf/GO- $\mathrm{Al}_{2} \mathrm{O}_{3}-1.5$ membrane with different emulsion concentrations (test conditions: operating pressure of 0.87 bar at ambient temperature and $\mathrm{pH}=7$ ).

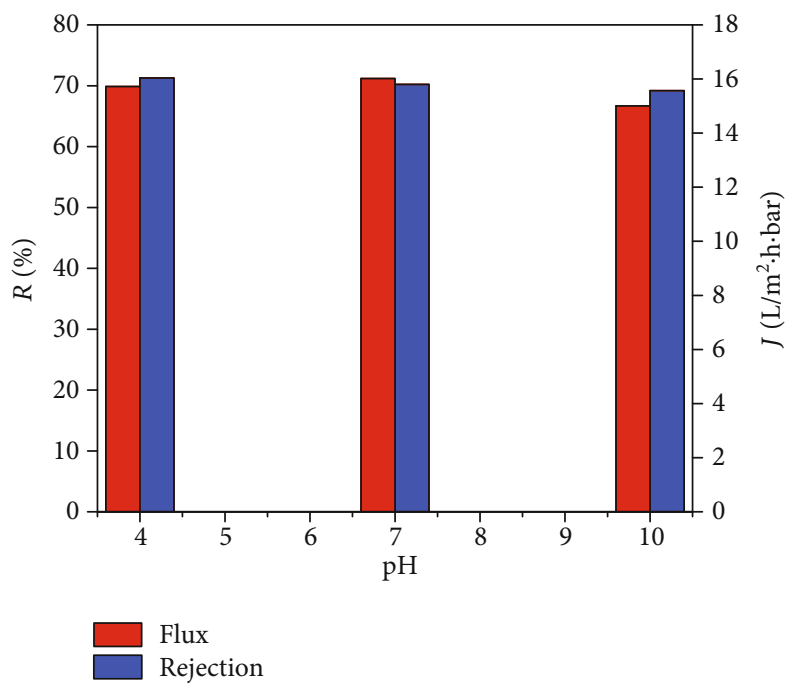

Figure 13: Permeate flux of PSf/GO- $\mathrm{Al}_{2} \mathrm{O}_{3}-1.5$ membrane at different $\mathrm{pH}$ (test conditions: operating pressure of 0.87 bar at ambient temperature and feed emulsion: $450 \mathrm{mg} / \mathrm{L}$ ).

$\mathrm{pH}=6$ ); the corresponding results are presented in Figures 9 and 10 . The obtained results showed an increase in the GO$\mathrm{Al}_{2} \mathrm{O}_{3}$ content of nanoparticles in the pristine PSf membrane from 0.5 to $1.5 \mathrm{wt} . \%$. This resulted in the oil rejection and the permeate flux of $66.22 \%$ and $11.76 \mathrm{~L} / \mathrm{m}^{2} \cdot \mathrm{h} \cdot \mathrm{bar}$ for the PSf $/ \mathrm{GO}-\mathrm{Al}_{2} \mathrm{O}_{3}-0.5$ membrane, $70.99 \%$ and $13.9 \mathrm{~L} / \mathrm{m}^{2} \cdot \mathrm{h} \cdot \mathrm{bar}$ for the PSf/GO- $\mathrm{Al}_{2} \mathrm{O}_{3}-1.0$ membrane, and $73.81 \%$ and $16.18 \mathrm{~L} / \mathrm{m}^{2} \cdot h \cdot b a r$ for the PSf $/ \mathrm{GO}-\mathrm{Al}_{2} \mathrm{O}_{3}-1.5$ membrane, respectively. The oil rejection and the permeate flux constantly increased according to the $\mathrm{GO}-\mathrm{Al}_{2} \mathrm{O}_{3}$ content of the

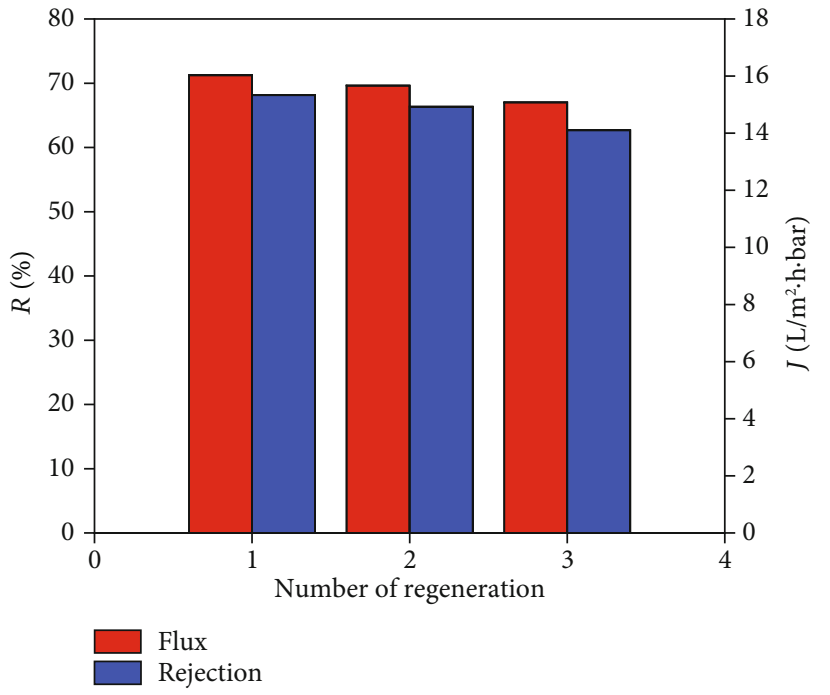

FIgURE 14: Rejection and permeate flux of PSf/GO- $\mathrm{Al}_{2} \mathrm{O}_{3}-1.5$ membrane after three cycles in $30 \mathrm{~min}$ (test conditions: operating pressure of 0.87 bar at ambient temperature and feed emulsion: $450 \mathrm{mg} / \mathrm{L})$.

TABLE 2: Irreversible fouling coefficient of pristine PSf and PSf/GO$\mathrm{Al}_{2} \mathrm{O}_{3}-1.5$ membranes.

\begin{tabular}{lccc}
\hline Membrane sample & $J_{\text {wo }}\left(\mathrm{L} / \mathrm{m}^{2} \cdot \mathrm{h} \cdot\right.$ bar $)$ & $J_{\mathrm{w}}\left(\mathrm{L} / \mathrm{m}^{2} \cdot \mathrm{h} \cdot\right.$ bar $)$ & $\mathrm{FR}_{\mathrm{w}}(\%)$ \\
\hline PSf & 14.13 & 11.49 & 18.68 \\
PSf/GO- $\mathrm{Al}_{2} \mathrm{O}_{3}-1.5$ & 16.76 & 14.61 & 12.83 \\
\hline
\end{tabular}

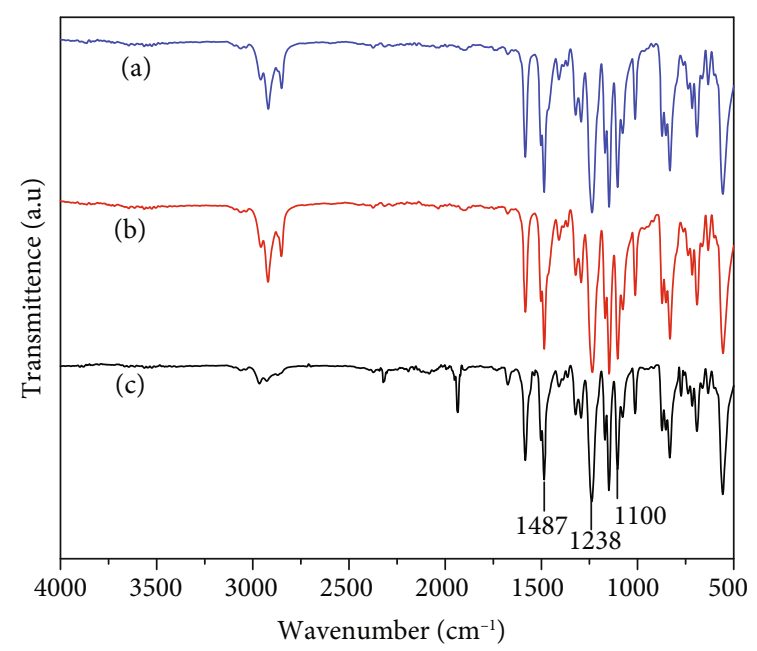

FIgURE 15: FT-IR spectra of PSf/GO- $\mathrm{Al}_{2} \mathrm{O}_{3}-1.5$ membranes after (a) the first, (b) the second, and (c) the third filtration.

membranes. When the GO- $\mathrm{Al}_{2} \mathrm{O}_{3}$ content was increased to 2.0 wt.\%, the rejection and flux of the PSf/GO- $\mathrm{Al}_{2} \mathrm{O}_{3}-2.0$ membrane dramatically decreased by $68.62 \%$ and $13.65 \mathrm{~L} / \mathrm{m}^{2} \cdot h \cdot b a r$, respectively. This decrease was probably due to the partial agglomeration, which led to the rougher surface, and the membrane porosity of the nanoparticleincorporated substrates $[46,47]$. 


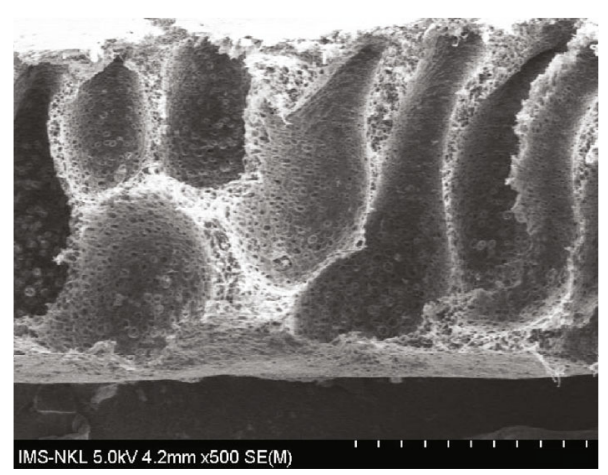

(a)

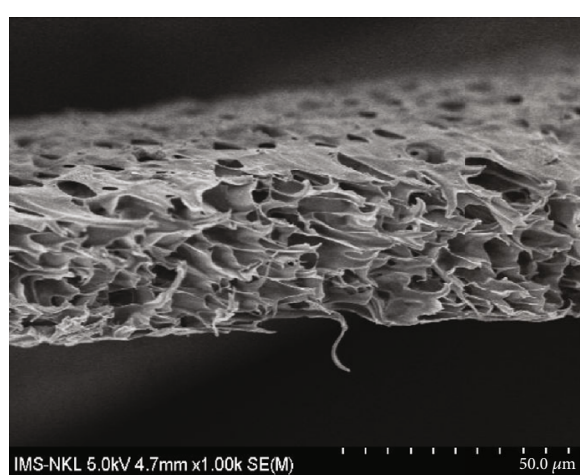

(b)

FIGURE 16: SEM images of the surface (a) and the cross-sectional images (b) of PSf/GO- $\mathrm{Al}_{2} \mathrm{O}_{3}-1.5$ membranes after the third filtration.

(2) Effect of Oil-in-Water Emulsion Concentrations. The effect of the oil/water emulsion concentration on the separation performance was also determined using the PSf/GO$\mathrm{Al}_{2} \mathrm{O}_{3}-1.5$ membrane. As shown in Figures 11 and 12, when the emulsion concentration increased from 450 to $750 \mathrm{mg} / \mathrm{L}$, the oil rejection decreased sharply from $73.81 \%$ to $45.64 \%$. This was attributed to the deposition of oil molecules on the membrane surface, thus increasing the resistance of the transport water.

In addition, the permeate flux of the membrane tended to decrease as the emulsion concentration increased; the permeate flux was maintained at $16.28 \mathrm{~L} / \mathrm{m}^{2} \cdot \mathrm{h} \cdot$ bar for $30 \mathrm{~min}$ at the concentration of $450 \mathrm{mg} / \mathrm{L}$. Meanwhile, the permeate flux was 9.34 and $11.10 \mathrm{~L} / \mathrm{m}^{2} \cdot \mathrm{h}$ for the concentration of 750 and $600 \mathrm{mg} / \mathrm{L}$ after $20 \mathrm{~min}$, respectively, then decreased sharply. The decrease in the permeate flux as the emulsion concentration increased could be attributed to the increase in viscosity of the emulsion, thus leading to the resistance of the mass transfer through the membrane.

(3) Effect of $\mathrm{pH}$. The effect of $\mathrm{pH}$ on the rate of oil rejection and the permeate flux of the prepared membrane (PSf/GO$\mathrm{Al}_{2} \mathrm{O}_{3}-1.5$ ) are presented in Figures 13 and 14. It can be seen that the oil rejection and the permeate flux changed slightly after $60 \mathrm{~min}$ when the $\mathrm{pH}$ was increased from 4.0 to 10 . This might be attributed to oil consisting of nonpolar hydrocarbon molecules; thus, at an acidic $\mathrm{pH}$, a positive charge was observed and/or the basic $\mathrm{pH}$ of the environment did not significantly affect the removal of oil during the operating time.

(4) Investigation of Irreversible Fouling Coefficient. The irreversible fouling coefficient $\left(\mathrm{FR}_{\mathrm{w}}\right)$ was used to evaluate the cleaning effect and the permeate flux recovery of the membranes. The $\mathrm{FR}_{\mathrm{w}}$ values of the modified membrane (PSf/GO- $\mathrm{Al}_{2} \mathrm{O}_{3}-1.5$ ) and the unmodified membrane (pristine PSf) are shown in Table 2. As shown, the irreversible fouling coefficient of the PSf/GO- $\mathrm{Al}_{2} \mathrm{O}_{3}-1.5$ membrane was $5.85 \%$ lower than that of the pristine PSf membrane in the entire process. This result revealed that the enhancement of the antifouling properties of the membrane was due to the modified membrane.
3.3.2. Reusability of the Membrane. Figure 14 shows the three cycles of the oil rejection $(R)$ and the permeate flux $(J)$ at the emulsion concentration $450 \mathrm{mg} / \mathrm{L}$ when treated with the PSf/GO- $\mathrm{Al}_{2} \mathrm{O}_{3}-1.5$ membrane. As the number of cycles increased, the oil rejection and the permeate flux significantly decreased from $71.24 \%$ to $67.01 \%$ and from $15.33 \mathrm{~L} / \mathrm{m}^{2} \cdot \mathrm{h} \cdot$ bar to $14.10 \mathrm{~L} / \mathrm{m}^{2} \cdot \mathrm{h} \cdot$ bar, respectively, after three cycles.

In addition, this result was proven by the FT-IR spectra of the recovered membranes. As shown in Figure 15, the characteristics of the functional groups of $\mathrm{O}=\mathrm{S}=\mathrm{O}$, phenyl, Al$\mathrm{O}-\mathrm{C}$, and methylene bonds were unchanged. Moreover, the SEM images (Figure 15) showed the outer surface and the cross-sectional photographs of the PSf/GO- $\mathrm{Al}_{2} \mathrm{O}_{3}-1.5$ membrane after three cycles. Compared with the pristine PSf/GO- $\mathrm{Al}_{2} \mathrm{O}_{3}-1.5$ membrane and after filtrations, the morphology of the cross-sectional and structural surface did not change, as presented in Figure 16(b). The experimental results for the separation of the oil (Figure 14) indicated that the filtration capacity remained almost unchanged for three cycles; the oil rejection was still $67.01 \%$ with the permeate flux of $14.10 \mathrm{~L} / \mathrm{m}^{2} \cdot \mathrm{h} \cdot \mathrm{bar}$. This indicated that the prepared membranes still had pore holes to maintain their filtration capacity.

\section{Conclusions}

In this research, $\mathrm{GO}-\mathrm{Al}_{2} \mathrm{O}_{3}$ nanoparticles were directly added to the PSf casting solution to synthesise a nanocomposite membrane via the common phase inversion method. The alumina-graphene oxide nanoparticles were prepared via a one-pot hydrothermal process. The addition of $\mathrm{GO}-\mathrm{Al}_{2} \mathrm{O}_{3}$ modified the structural morphology of the membrane, and the water contact angle reduced while the surface area and the porosity increased. The experimental results also showed that the oil rejection and the permeate flux of an oil-in-water emulsion in the PSf/GO- $\mathrm{Al}_{2} \mathrm{O}_{3}-1.5$ membrane substantially increased as compared to those of the PSf/GO membrane and the pristine PSf membrane. In addition, with this incorporation, the antifouling properties of the membranes were enhanced. The PSf/GO- $\mathrm{Al}_{2} \mathrm{O}_{3}$ membrane showed great potential for oily wastewater treatment applications. 


\section{Data Availability}

The data used to support the findings of this study are available from the corresponding author upon request.

\section{Additional Points}

Highlights. (i) The alumina-graphene oxide ( $\left.\mathrm{GO}-\mathrm{Al}_{2} \mathrm{O}_{3}\right)$ nanoparticles were prepared via a one-pot hydrothermal procedure. (ii) $\mathrm{GO}-\mathrm{Al}_{2} \mathrm{O}_{3}$ nanoparticles were directly added into a PSf casting solution via a phase inversion method. (iii) Various percentages of $\mathrm{GO}-\mathrm{Al}_{2} \mathrm{O}_{3}$ were used for pristine PSf membrane enhancement. (iv) The $1.5 \mathrm{wt} \%$ GO$\mathrm{Al}_{2} \mathrm{O}_{3} /$ PSf membrane exhibited excellent separation performance for oil from oily wastewater.

\section{Conflicts of Interest}

The authors declare that they have no conflicts of interest.

\section{Acknowledgments}

This research has been financially supported by a Grant (No. 104.06-2017.56) from the Vietnam National Foundation for Science and Technology Development (NAFOSTED).

\section{References}

[1] L. Li, L. Ding, Z. Tu, Y. Wan, D. Clausse, and J. L. Lanoisellé, "Recovery of linseed oil dispersed within an oil-in-water emulsion using hydrophilic membrane by rotating disk filtration system," Journal of Membrane Science, vol. 342, no. 1-2, pp. 70-79, 2009.

[2] L. J. Stack, P. A. Carney, H. B. Malone, and T. K. Wessels, "Factors influencing the ultrasonic separation of oil-in-water emulsions," Ultrasonics Sonochemistry, vol. 12, no. 3, pp. 153-160, 2005.

[3] K. Bensadok, M. Belkacem, and G. Nezzal, "Treatment of cutting oil/water emulsion by coupling coagulation and dissolved air flotation," Desalination, vol. 206, no. 1-3, pp. 440-448, 2007.

[4] E. R. Binner, J. P. Robinson, S. W. Kingman et al., "Separation of oil/water emulsions in continuous flow using microwave heating," Energy \& Fuels, vol. 27, no. 6, pp. 3173-3178, 2013.

[5] Z. L. Kiss, L. Kocsis, G. Keszthelyi-Szabó, C. Hodúr, and Z. László, "Treatment of oily wastewater by combining ozonation and microfiltration," Desalination and Water Treatment, vol. 55, no. 13, pp. 3662-3669, 2014.

[6] J. Jeganathan, G. Nakhla, and A. Bassi, "Hydrolytic pretreatment of oily wastewater by immobilized lipase," Journal of Hazardous Materials, vol. 145, no. 1-2, pp. 127-135, 2007.

[7] J. S. Eow and M. Ghadiri, "Electrostatic enhancement of coalescence of water droplets in oil: a review of the technology," Chemical Engineering Journal, vol. 85, no. 2-3, pp. 357-368, 2002.

[8] M. A. Shannon, P. W. Bohn, M. Elimelech, J. G. Georgiadis, B. J. Marinas, and A. M. Mayes, "Science and technology for water purification in the coming decades," Nature, vol. 452, no. 7185, pp. 301-310, 2008.
[9] B. E. Logan and M. Elimelech, "Membrane-based processes for sustainable power generation using water," Nature, vol. 488, no. 7411, pp. 313-319, 2012.

[10] Q. Shi, L. Ni, Y. Zhang, X. Feng, Q. Chang, and J. Meng, "Poly(p-phenylene terephthamide) embedded in a polysulfone as the substrate for improving compaction resistance and adhesion of a thin film composite polyamide membrane," Journal of Materials Chemistry A, vol. 5, no. 26, pp. 1361013624, 2017.

[11] G. Kapantaidakis, "Gas permeation through PSF-PI miscible blend membranes," Journal of Membrane Science, vol. 110, no. 2, pp. 239-247, 1996.

[12] J. H. Jhaveri and Z. V. P. Murthy, "A comprehensive review on anti-fouling nanocomposite membranes for pressure driven membrane separation processes," Desalination, vol. 379, pp. 137-154, 2016.

[13] E. Igbinigun, Y. Fennell, R. Malaisamy, K. L. Jones, and V. Morris, "Graphene oxide functionalized polyethersulfone membrane to reduce organic fouling," Journal of Membrane Science, vol. 514, pp. 518-526, 2016.

[14] B. M. Ganesh, A. M. Isloor, and A. F. Ismail, "Enhanced hydrophilicity and salt rejection study of graphene oxidepolysulfone mixed matrix membrane," Desalination, vol. 313, pp. 199-207, 2013.

[15] H. R. Pant, C. H. Park, L. D. Tijing, A. Amarjargal, D. H. Lee, and C. S. Kim, "Bimodal fiber diameter distributed graphene oxide/nylon-6 composite nanofibrous mats via electrospinning," Colloids and Surfaces A: Physicochemical and Engineering Aspects, vol. 407, pp. 121-125, 2012.

[16] H. R. Pant, B. Pant, P. Pokharel et al., "Photocatalytic $\mathrm{TiO}_{2}-$ RGO/nylon-6 spider-wave-like nano-nets via electrospinning and hydrothermal treatment," Journal of Membrane Science, vol. 429, pp. 225-234, 2013.

[17] H. W. Kim, H. W. Yoon, et al.S. M. Yoon et al., "Selective gas transport through few-layered graphene and graphene oxide membranes," Science, vol. 342, no. 6154, pp. 91-95, 2013.

[18] H. Li, Z. Song, X. Zhang et al., "Ultrathin, molecular-sieving graphene oxide membranes for selective hydrogen separation," Science, vol. 342, no. 6154, pp. 95-98, 2013.

[19] Y. P. Tang, J. X. Chan, T. S. Chung, M. Weber, C. Staudt, and C. Maletzko, "Simultaneously covalent and ionic bridging towards antifouling of GO-imbedded nanocomposite hollow fiber membranes," Journal of Materials Chemistry A, vol. 3, no. 19, pp. 10573-10584, 2015.

[20] M. Chhowalla, H. S. Shin, G. Eda, L.-J. Li, K. P. Loh, and H. Zhang, "The chemistry of two-dimensional layered transition metal dichalcogenide nanosheets," Nature Chemistry, vol. 5, no. 4, pp. 263-275, 2013.

[21] J. Liu, J. Tang, and J. J. Gooding, "Strategies for chemical modification of graphene and applications of chemically modified graphene," Journal of Materials Chemistry, vol. 22, no. 25, pp. 12435-12452, 2012.

[22] H. M. Park, K. Y. Jee, and Y. T. Lee, "Preparation and characterization of a thin-film composite reverse osmosis membrane using a polysulfone membrane including metal-organic frameworks," Journal of Membrane Science, vol. 541, pp. 510-518, 2017.

[23] R. Ramezani Darabi, M. Jahanshahi, and M. Peyravi, “A support assisted by photocatalytic $\mathrm{Fe}_{3} \mathrm{O}_{4} / \mathrm{ZnO}$ nanocomposite for thin-film forward osmosis membrane," Chemical Engineering Research and Design, vol. 133, pp. 11-25, 2018. 
[24] X. Hu, Y. Yu, J. Zhou et al., “The improved oil/water separation performance of graphene oxide modified $\mathrm{Al} 2 \mathrm{O} 3$ microfiltration membrane," Journal of Membrane Science, vol. 476, pp. 200-204, 2015.

[25] Y. Pan, T. Wang, H. Sun, and W. Wang, "Preparation and application of titanium dioxide dynamic membranes in microfiltration of oil-in-water emulsions," Separation and Purification Technology, vol. 89, pp. 78-83, 2012.

[26] D. Ji, C. Xiao, S. An, J. Zhao, J. Hao, and K. Chen, "Preparation of high-flux PSF/GO loose nanofiltration hollow fiber membranes with dense-loose structure for treating textile wastewater," Chemical Engineering Journal, vol. 363, pp. 33-42, 2019.

[27] S. Nasseri, S. Ebrahimi, M. Abtahi, and R. Saeedi, "Synthesis and characterization of polysulfone/graphene oxide nanocomposite membranes for removal of bisphenol A from water," Journal of Environmental Economics and Management, vol. 205, pp. 174-182, 2018.

[28] T. Sirinupong, W. Youravong, D. Tirawat, W. J. Lau, G. S. Lai, and A. F. Ismail, "Synthesis and characterization of thin film composite membranes made of $\mathrm{PSF}-\mathrm{TiO}_{2} / \mathrm{GO}$ nanocomposite substrate for forward osmosis applications," Arabian Journal of Chemistry, vol. 11, no. 7, pp. 1144-1153, 2018.

[29] J. Yin and B. Deng, "Polymer-matrix nanocomposite membranes for water treatment," Journal of Membrane Science, vol. 479, pp. 256-275, 2015.

[30] K. Hu, D. D. Kulkarni, I. Choi, and V. V. Tsukruk, "Graphenepolymer nanocomposites for structural and functional applications," Progress in Polymer Science, vol. 39, no. 11, pp. 1934-1972, 2014.

[31] C. Zhao, X. Xu, J. Chen, and F. Yang, "Effect of graphene oxide concentration on the morphologies and antifouling properties of PVDF ultrafiltration membranes," Journal of Environmental Chemical Engineering, vol. 1, no. 3, pp. 349-354, 2013.

[32] J. Lee, H.-R. Chae, Y. J. Won et al., "Graphene oxide nanoplatelets composite membrane with hydrophilic and antifouling properties for wastewater treatment," Journal of Membrane Science, vol. 448, pp. 223-230, 2013.

[33] H. T. V. Nguyen, T. H. A. Ngo, K. D. Do et al., "Preparation and characterization of a hydrophilic polysulfone membrane using graphene oxide," Journal of Chemistry, vol. 2019, Article ID 3164373, 10 pages, 2019.

[34] W. S. Hummers Jr. and R. E. Offeman, "Preparation of graphitic oxide," Journal of the American Chemical Society, vol. 80, no. 6, article 1339, 1958.

[35] T. Nakajima and Y. Matsuo, "Formation process and structure of graphite oxide," Carbon, vol. 32, no. 3, pp. 469-475, 1994.

[36] D. C. Marcano, D. V. Kosynkin, J. M. Berlin et al., "Correction to improved synthesis of graphene oxide," ACS Nano, vol. 12, no. 2, article 2078, 2018.

[37] Z. Wang, H. Yu, J. Xia et al., "Novel GO-blended PVDF ultrafiltration membranes," Desalination, vol. 299, pp. 50-54, 2012.

[38] J.-F. Blanco, J. Sublet, Q. T. Nguyen, and P. Schaetzel, "Formation and morphology studies of different polysulfones-based membranes made by wet phase inversion process," Journal of Membrane Science, vol. 283, no. 1-2, pp. 27-37, 2006.

[39] C. W. Phillip, Separation Process Engineering: Includes Mass Transfer Analysis (4th Edition) New Jersey, Statele Unite: Pearson Education, 2006.

[40] T. Szabó, O. Berkesi, P. Forgó et al., "Evolution of surface functional groups in a series of progressively oxidized graphite oxides," Chemistry of Materials, vol. 18, no. 11, pp. 2740 2749, 2006.

[41] G. Nechifor, S. I. Voicu, A. C. Nechifor, and S. Garea, "Nanostructured hybrid membrane polysulfone-carbon nanotubes for hemodialysis," Desalination, vol. 241, no. 1-3, pp. 342348, 2009.

[42] E. M. van Wagner, A. C. Sagle, M. M. Sharma, Y. H. la, and B. D. Freeman, "Surface modification of commercial polyamide desalination membranes using poly(ethylene glycol) diglycidyl ether to enhance membrane fouling resistance," Journal of Membrane Science, vol. 367, no. 1-2, pp. 273-287, 2011.

[43] D. C. L. Vasconcelos, E. H. M. Nunes, and W. L. Vasconcelos, "AES and FTIR characterization of sol-gel alumina films," Journal of Non-Crystalline Solids, vol. 358, no. 11, pp. 13741379, 2012.

[44] A. A. Izadpanah and A. Javidnia, "The ability of a nanofiltration membrane to remove hardness and ions from diluted seawater," Water, vol. 4, no. 2, pp. 283-294, 2012.

[45] G.-R. Xu, J.-N. Wang, and C.-J. Li, "Strategies for improving the performance of the polyamide thin film composite (PATFC) reverse osmosis (RO) membranes: surface modifications and nanoparticles incorporations," Desalination, vol. 328, pp. 83-100, 2013.

[46] H. Gang, "Development and fabrication of thin film composite (Tfc) membranes for engineered osmosis processes," Journal of Chemical Information and Modeling, vol. 53, pp. 16891699, 2013.

[47] S. Xia and M. Ni, "Preparation of poly(vinylidene fluoride) membranes with graphene oxide addition for natural organic matter removal," Journal of Membrane Science, vol. 473, pp. 54-62, 2015. 